\title{
The Perception of Governmental Support in The Context of Competitiveness of SMEs in the Czech Republic
}

\author{
- Dobeš Kamil, Kot Sebastian, Kramoliš Jan, Sopková Gabriela
}

\begin{abstract}
Whether or not an entrepreneur develops the enterprise successfully and increases competitiveness depends on many factors. All businesses, however, are inherently connected with the business environment which significantly influences their performance. In this regard, the state is among the most important factors. It also performs many other roles through which it may be either helpful or harmful in the eyes of a business owner, e.g. it determines the legislative framework of entrepreneurship, sets conditions for starting a business and regulates competition. The way the role of the state is perceived by small and medium-sized enterprises was researched in 2015 as a part of a project at Tomas Bata University in Zlín. The research analysed data from 1,141 respondents from all regions of the Czech Republic and included, among others, the question of the state's role in the business environment. The presented paper covers three selected areas of the state's influence on the business environment: creating favourable conditions for the business environment, governmental financial support of entrepreneurs, and administrative burden on entrepreneurs. These areas were also examined with the emphasis on the analysis of differences between the perception of entrepreneurs from different industries and entrepreneurs with different sizes of their businesses. It was revealed that entrepreneurs were very critical to the state's role in the business environment; in particular, $60 \%$ of respondents disagree with the fact that the state creates favourable conditions for business in the Czech Republic. It was proved that the line of business of enterprises correlates with perception of the state's role within the business environment. The research into perception of a governmental financial support was proved to be dependent on a company size which may signal the support of certain company sizes and influencing their competitiveness.
\end{abstract}

Keywords: business environment, small and medium-sized enterprises, state

JEL classification H70, L26, M13, M21

\section{INTRODUCTION}

Small and medium-sized enterprises (SMEs) are of great importance for the world economy because they promote competitive dynamics of economic systems and directly or indirectly affect large companies, especially in the field of the growth of efficiency and innovation (Pavelková et al., 2009).

Many authors examine business environment from different perspectives. Bartoš et al. (2015) examines selected aspects of the business environment in the SME segment and concludes that business environment is sensitive to the commercial banks' approach to financing their needs. 
Hamplová and Provazniková (2015) analyse business conditions in the Czech Republic and focus their attention on the identification of non-market factors, including mainly institutional and administrative burden, which influence entrepreneurship on the level of SMEs. Chládková (2015) focuses her research on the opportunities, threats, strengths, and weaknesses of the business environment, and declared competition as the most important threat for the entrepreneurs in this region.

In the last decade, it became obvious that the so-called newly acquired comparative advantages began to claim dominant positions on international markets, they include for example: an effective implementation of foreign investments and knowhow, a more sophisticated work organization, better availability of loans for small and medium-sized enterprises, an access to external financing of domestic enterprises or to other development resources, and taking advantage of knowledge of a local environment and expanding business partnerships (Baláž, Hamara, Sopková, 2015).

The presented paper is structured as follows: the theoretical part presents the problems of SMEs and their importance for domestic and international economies. Attention is paid to the role of the state and views of its role from previous studies. The second part specifies the objective, sets the research questions, and describes the research methodology. Finally, the paper describes the results and the authors critically review key findings in the part of discussion.

\section{THEORETICAL BACKGROUND}

Quality business environment creates favourable conditions for the development of SMEs as they represent an important part of the national economic system. Not only economic criteria but also social, educational, cultural, and other factors are playing an important role in this process (Ključnikov et al., 2016, Smekalova et al., 2014). As Mathur (2011) states, SMEs play an essential role in financing welfare of local communities as well as in cultural and sports life in regions. The loss of SME as a sponsor or patron due to a crisis has a substantial impact on existing social structures. Following this, Henderson and Weiler (2010) state that SMEs could be characterised as the most important catalyst for the economic growth. In the European Union and the USA, $99 \%$ of all companies are in the SME segment (Bhaird, 2010).

The fundamental prerequisite for successful management and development of all businesses is a favourable business environment in which the state supports and protects economic competition, creates clear and stable rules, and effectively ensures compliance by all market participants while minimizing administrative barriers towards entrepreneurs. A positive perception of the business situation by society might mean a greater interest in starting a business which can further lead to a higher rate of GDP and higher employment rates. (Belás et al., 2015).

While there can be deficiencies in the institutional framework anywhere, it is normally argued that problems are especially serious in less developed economies. Literature often concentrates on weaknesses in legal systems, high levels of state regulation, and corruption (La Porta et al. 1999; Djankov et al. 2002). Estrin et al. (2013) confirmed that the increase in entrepreneurship will be pushed out by governmental activism. 
SMEs are the single most important factor when achieving the objectives set by the Europe 2020 strategy and creating environment suitable for their dynamic development and consistent implementation of the European Charter for SMEs is the core of the EU economic policy (Eric et al., 2011). The character of companies from the SME sector leads to a close relationship between the development of enterprises and the local and regional development. A high level of regional development increases competitiveness of the local system and facilitates further economic development (Zuzek, D. K., 2015).

In today's fierce competition, SMEs gradually developed into the dominant force for the national economic and social development (Shuying and Mei, 2014). Belanová (2014) states that a quality business environment creates conditions for a long-term sustainable economic growth, and is a basic prerequisite for business development and growth of competitiveness of the country on an international scale. A favourable business environment can also help in competitiveness of specific companies or a whole region. A favorable business environment in accordance with Butoracová et al. (2009) is an important prerequisite for competitiveness of Slovakia and its regions.

The quality of the business environment is based on many factors. In addition to banks or business partners, they primarily include the state which sets the legislative framework which the entrepreneur must follow. The role of the state as the principal element, which sets up the external factors of a business environment, cannot be underestimated. The state is responsible for such substantial elements of corporate surroundings as legislative conditions and their application in business practice, social aspects, and an overall economic environment (Májková, 2012; Kubátová et al., 2012; Kaplanova, 2016).

The setting of favourable legislative conditions can be a competitive advantage for companies in the country. There are several ways to measure and assess the competitiveness of countries. Probably the most widely used index of measuring competitiveness of countries is the Global Competitiveness Index compiled annually by the World Economic Forum (Kordalska and Olczyk, 2016). The business environment is often assessed by Doing Business indicators index which is published annually by the World Bank. The basic indicators of this index include, for example, conditions for starting a business, protecting investors, paying taxes, resolving insolvency and others (Balcerzak, 2009). The Index of Economic Freedom is another important indicator of the quality of a country's business environment.

In today's globalised economy, SMEs are facing ever increasing competitive pressures (Muhammad et al., 2010; Whittaker, Burns \& Beveren 2003). They need to acquire new market information and knowledge to remain competitive. As such, a common strategy is to develop social networks with other SMEs (Whittaker et al, 2003). SMEs are the most vulnerable and very susceptible to competition from similarly structured companies and large corporations. Traditionally, SMEs have several advantages over large companies due to their size and flexibility in adapting to changes. It has also been found that market and learning-oriented SMEs, facing strong competition, tend to be more innovative and resilient (Salavou et al. 2004). 


\section{RESEARCH AIM AND METHODOLOGY}

The aim of this article is to examine the influence of a company size and industry on the differences in perception of the state's role in its business environment. The research focuses on the segment of SMEs in the Czech Republic in 2015.

In particular, 1,650 companies were randomly selected from the Albertina database and all of them were addressed either by e-mail or by phone with the request to fill in the questionnaire placed at:

https://docs.google.com/forms/d/e/1FAIpQLScfMtKdtx8faYHb8ZHf5GybfmmxB62ggV lyvlrfekW0CNh-nA/viewform.

The data was provided by 1,141 owners of SMEs in 14 regions of the Czech Republic. The questionnaire consisted of 52 questions. The first nine questions covered respondents and their structure in relation to their education, gender, age, residency and size of a firm, the length of time and area of business, motives for starting a business, and the most important characteristics of an entrepreneur were analysed. The rest of the questions were focused on the business environment and included a rating of 1-5 scale, from strongly agree (1) to strongly disagree (5).

In terms of a company size, the structure of the examined sample was as follows: $65 \%$ were Micro Enterprises (<10 employees), 27\% Small Enterprises (10 - 50 employees), and 8\% Mediumsized Enterprises (50 - 250 employees). In terms of ratios, this structure is consistent with the distribution of companies in the economy.

The research also monitored primary areas of business of each company. If a clear single line of business was not to be determined, the company was included into the Combination category. In terms of industry, the structure of the studied sample was as follows: Trade (24\%), Manufacturing $(16 \%)$, Construction (12\%), Transportation (4\%), Agriculture (2\%), Other services $(32 \%)$, and Combination (10\%). The Combination category was created due to the inability of some entrepreneurs to clearly identify the primary area of their business.

The paper focuses on analysing partial results of the research in three areas for which SMEs were surveyed as to their current attitude toward selected factors of the Czech business environment:

\section{Perception of the state creating a favourable business environment for SMEs:}

Q1: At least 20\% of SMEs in the Czech Republic claim that the state creates a favourable business environment.

Q1a: Perception of the state creating a favourable business environment for SMEs based on the line of business.

Q1b: Perception of the state creating a favourable business environment for SMEs based on the company size.

Perception of appropriateness of the setup of the forms of governmental financial support of business:

Q2: More than 50\% SMEs in the Czech Republic perceive the setup of the forms of governmental financial support of business as inappropriate. 
Q2a: Perception of appropriateness of the setup of the forms of governmental financial support of business is based on the line of business. .

Q2b: Perception of appropriateness of the setup of the forms of governmental financial support of business is based on the company size.

\section{Perception of reduction in the administrative burden over the last five years:}

Q3: More than 60\% of SMEs disagree with the fact that the administrative burden has reduced over the last five years.

Q3a: Perception of reduction in the administrative burden over the last five years is based on the line of business.

Q3b: The perception of reduction in administrative burden over the last five years is based on the company size.

An ordinal mean value $[\operatorname{med}(\mathrm{x})]$ was determined for each scaled answer and a discrete ordinal variance (dorvar) was computed. Pearson's Chi-squared test was used for dependency testing. Xsquared tests were conducted at the 5\% significance level. Monte Carlo Simulation was used due to under-representation of several groups at a time. This method addresses the limitation while calculating a more exact p-value.

\section{RESULTS}

The first research question (Q1) focuses on analysing how the companies surveyed perceive the role of the state in shaping a favourable business environment for SMEs. The question was further analysed in relation to the line of business and the company size.

The research revealed that $8.67 \%$ of entrepreneurs agree with the fact that the state manages to create a favourable business environment. A neutral position was indicated by $30.32 \%$ of respondents while majority of surveyed entrepreneurs (60.01\%) disagree with the statement. The research question Q1 - at least 20\% of SMEs in the Czech Republic agree with the fact that the state creates a favourable business environment - has not been proved.

Table 1 shows the nominal values for the examined ClaimQ1a in relation to the line of business of the companies surveyed. The table also lists the ordinal mean values and discrete ordinal variances.

Tab. 1 - Pivot table for Q1a absolute frequency and Statistical characteristics. Source: authors

\begin{tabular}{|c|c|c|c|c|c|c|c|c|}
\hline \multirow{2}{*}{$\begin{array}{l}\text { Q1 / } \\
\text { sector }\end{array}$} & \multicolumn{2}{|c|}{ Agree (n) } & - & \multicolumn{2}{|c|}{ Disagree $(n)$} & \multirow{2}{*}{$\begin{array}{c}\text { Total } \\
(n)\end{array}$} & \multicolumn{2}{|c|}{$\begin{array}{l}\text { Statistical } \\
\text { indicators }\end{array}$} \\
\hline & $\begin{array}{c}\text { Completely } \\
\text { agree }\end{array}$ & agree & $\begin{array}{l}\text { No } \\
\text { idea }\end{array}$ & disagree & $\begin{array}{c}\text { Completely } \\
\text { disagree }\end{array}$ & & $\operatorname{med}(x)$ & dorvar \\
\hline Agriculture & 0 & 5 & 11 & 12 & 1 & 29 & 3.36 & 0.85 \\
\hline
\end{tabular}




\begin{tabular}{|l|c|c|c|c|c|c|c|c|}
\hline $\begin{array}{l}\text { Construction } \\
\text { industry }\end{array}$ & 0 & 8 & 40 & 67 & 17 & 132 & 3.77 & 0.80 \\
\hline Manufacturing & 0 & 12 & 62 & 89 & 19 & 182 & 3.69 & 0.79 \\
\hline Trade & 1 & 26 & 79 & 141 & 25 & 272 & 3.71 & 0.83 \\
\hline Transportation & 2 & 5 & 15 & 23 & 4 & 49 & 3.61 & 0.97 \\
\hline Other services & 0 & 31 & 109 & 195 & 28 & 363 & 3.71 & 0.77 \\
\hline Combination & 0 & 9 & 30 & 58 & 17 & 114 & 3.81 & 0.85 \\
\hline Total $(n)$ & 3 & 96 & 346 & 585 & 111 & 1141 & & \\
\hline
\end{tabular}

The research question Q1a addresses whether the line of business is a factor for how entrepreneurs perceive the role a state in creating of the business environment. Agriculture showed the highest level of agreement $[\operatorname{med}(\mathrm{x})=3.36)]$ with the examined claim despite the fact that the sector is burdened with a high degree of market regulation. Transportation shows the greatest heterogeneity (dorvar $=0.97$ ) for this claim. Other Services was the sector showing the smallest heterogeneity (dorvar $=0.77$ ), mostly with the disagreeing opinion towards the examined claim.

The polarity of views on Q1 is graphically illustrated by the Gauss chart below (blue) with a polynomial trend line (black thin) with the reliability value $\left(\mathrm{R}^{2}\right)$ where the following applies to the axis $\mathrm{x}$ scale: $0=$ strongly disagree, $1=$ strongly agree.

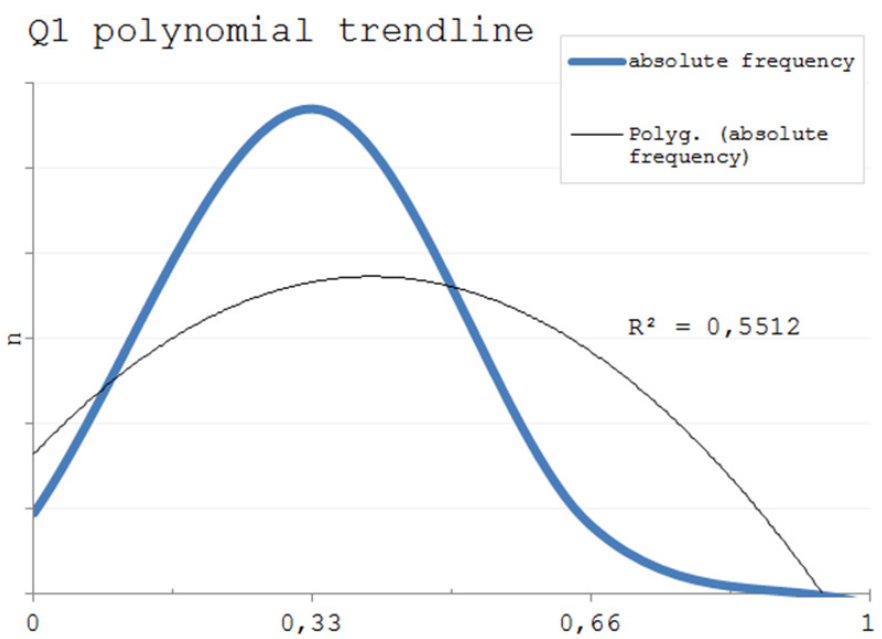

Fig. 1 - Q1 line chart with trendline. Source: authors

Here, the line chart represents an opinion polarity using simple Gauss distribution model. The graph shows that a moderately disagreeing opinion largely prevails. The trend line also suggests greater expressiveness in the disagreeing field. Assuming that the more the $\mathrm{R}^{2}$ approximates to 1 , the more reliable the results, it means a mean reliability $\left(\mathrm{R}^{2}=0.5512\right)$ in this case. 
Table 2 shows the results of testing the relationships in analysing Research Question Q1a. The Pearson's Chi-squared test with the significance level of $\alpha=0.05$ was used.

Tab. 2 - Q1a Chi-squared Test and p-value. Source: authors

Pearson's Chi-squared test with simulated p-value (based on 5000 replicates)

$\mathrm{H}_{0}$ : Variables are independent (no interaction between variables)

$\mathrm{H}_{1}$ : Variables are dependent (interaction between variables)

$\chi^{2}=45.397 ; \mathrm{DF}=\mathrm{n} / \mathrm{a} ; \mathrm{p}$-value $=0.012$

With the results in Table 2 showing that a statistically significant relationship between the line of business and how entrepreneurs perceive the role of the state in creating a business environment $(\mathrm{p}$-value $=0.012)$ was proved. Therefore, it can be concluded that Research Question Q1a has been proved.

Table 3 shows the nominal values for the examined Claim Q1b in relation to the size of surveyed companies. The table also lists the ordinal mean values and discrete ordinal variances.

Tab. 3 - Pivot table for Q1b absolute frequency and Statistical characteristics. Source: authors

\begin{tabular}{|c|c|c|c|c|c|c|c|c|}
\hline \multirow{2}{*}{$\begin{array}{l}\text { Q1 / } \\
\text { number of } \\
\text { employees } \\
\text { (company } \\
\text { size) }\end{array}$} & \multicolumn{2}{|c|}{ Agree (n) } & \multirow{2}{*}{$\begin{array}{c}- \\
\text { No } \\
\text { idea }\end{array}$} & \multicolumn{2}{|c|}{ Disagree $(n)$} & \multirow{2}{*}{$\begin{array}{c}\text { Total } \\
\text { (n) }\end{array}$} & \multicolumn{2}{|c|}{$\begin{array}{l}\text { Statistical } \\
\text { indicators }\end{array}$} \\
\hline & $\begin{array}{c}\text { Completely } \\
\text { agree }\end{array}$ & agree & & $\begin{array}{l}\text { disa- } \\
\text { gree }\end{array}$ & $\begin{array}{c}\text { Completely } \\
\text { disagree }\end{array}$ & & $\operatorname{med}(x)$ & dorvar \\
\hline$<10$ & 2 & 66 & 220 & 382 & 70 & 740 & 3.71 & 0.82 \\
\hline $10-50$ & 1 & 20 & 95 & 156 & 34 & 306 & 3.74 & 0.80 \\
\hline $50-250$ & 0 & 10 & 31 & 47 & 7 & 95 & 3.64 & 0.82 \\
\hline Total (n) & 3 & 96 & 346 & 585 & 111 & 1141 & & \\
\hline
\end{tabular}

The research question Q1b addresses whether the company size is a factor of how entrepreneurs perceive the role the state in creating of a business environment. Medium-sized Enterprises (50 - 250 employees) showed the highest level of agreement $[(\operatorname{med}(x)=3.64)]$ with the claim above. On the other hand, Small Enterprises (10 - 50 employees) expressed the smallest degree of agreement $[(\operatorname{med}(\mathrm{x})=3.64)]$; the answers of the latter also showed the greatest homogeneity (dorvar $=0.803)$.

Table 4 shows the results of testing the relationships in analysing the Research Question Q1b. The Pearson's Chi-squared test with the significance level of $\alpha=0.05$ was used.

Tab. 4 - Q1b Chi-squared Test and p-value. Source: authors

Pearson's Chi-squared test with simulated p-value (based on 5000 replicates)

$\mathrm{H}_{0}$ : Variables are independent (no interaction between variables)

$\mathrm{H}_{1}$ : Variables are dependent (interaction between variables)

$\chi^{2}=3.898 ; \mathrm{DF}=\mathrm{n} / \mathrm{a} ; \mathrm{p}$-value $=0.875$ 
As the results in Table 4 show that a statistically significant relationship between the company size and how entrepreneurs perceive the role of the state in creating a business environment was not proved, it can be therefore concluded that the Research Question Q1b has not been proved.

The second research question $(\mathrm{Q} 2)$ focuses on analysing whether entrepreneurs perceive the setup of a governmental financial support of business as appropriate. The question was further analysed in relation to the line of business and the company size.

The research revealed that only $9.55 \%$ of entrepreneurs see the forms of governmental financial support as set adequately. More than half of the entrepreneurs surveyed (59.07\%) disagree with this claim. A neutral statement was indicated by $10.87 \%$ of the respondents. To sum up, most of the entrepreneurs are dissatisfied with the setup of governmental support of entrepreneurship. The research question Q2 - over 50\% of SMEs in the country see the state's financial support of entrepreneurship as set inadequately - has been proved.

Table 5 shows the nominal values for the examined Claim Q2a in relation to the line of business of the companies surveyed. The table also lists the ordinal mean values and discrete ordinal variances.

Tab. 5 - Pivot table for Q2a absolute frequency and Statistical characteristics. Source: authors

\begin{tabular}{|c|c|c|c|c|c|c|c|c|}
\hline \multirow{2}{*}{$\begin{array}{l}\text { Q2 / } \\
\text { sector }\end{array}$} & \multicolumn{2}{|c|}{ Agree (n) } & \multirow{2}{*}{$\begin{array}{c}- \\
\text { No } \\
\text { idea }\end{array}$} & \multicolumn{2}{|c|}{ Disagree $(n)$} & \multirow{2}{*}{$\begin{array}{l}\text { Total } \\
\text { (n) }\end{array}$} & \multicolumn{2}{|c|}{$\begin{array}{l}\text { Statistical } \\
\text { indicators }\end{array}$} \\
\hline & $\begin{array}{c}\text { Completely } \\
\text { agree }\end{array}$ & agree & & disagree & $\begin{array}{c}\text { Completely } \\
\text { disagree }\end{array}$ & & $\operatorname{med}(x)$ & dorvar \\
\hline Agriculture & 0 & 3 & 9 & 13 & 4 & 29 & 3.69 & 0.91 \\
\hline $\begin{array}{l}\text { Construction } \\
\text { industry }\end{array}$ & 0 & 8 & 45 & 55 & 24 & 132 & 3.74 & 0.89 \\
\hline $\begin{array}{l}\text { Manufactur- } \\
\text { ing }\end{array}$ & 0 & 16 & 50 & 91 & 25 & 182 & 3.77 & 0.86 \\
\hline Trade & 0 & 25 & 92 & 120 & 35 & 272 & 3.66 & 0.88 \\
\hline $\begin{array}{l}\text { Transporta- } \\
\text { tion }\end{array}$ & 0 & 2 & 18 & 25 & 4 & 49 & 3.68 & 0.71 \\
\hline Other services & 2 & 39 & 117 & 171 & 34 & 363 & 3.64 & 0.87 \\
\hline Combination & 0 & 14 & 27 & 55 & 18 & 114 & 3.79 & 0.94 \\
\hline Total (n) & 2 & 107 & 358 & 530 & 144 & 1141 & & \\
\hline
\end{tabular}

The research question Q2a addresses whether the line of business is a factor in perceiving the setup of governmental financial support of entrepreneurship as appropriate. In this claim, Other Services companies expressed the highest level of agreement $[\operatorname{med}(x)=3.64)]$. The lowest levels of agreement $[\operatorname{med}(\mathrm{x})=3.79)]$ were expressed by entrepreneurs that do business in multiple areas (Combination) and their responses showed the highest heterogeneity (dorvar $=0.94)$.

The polarity of views on Q2 is visualised by the Gauss chart below (blue) with a polynomial trend line (black thin) with the reliability value $\left(\mathrm{R}^{2}\right)$ where the following applies to the axis $\mathrm{x}$ scale: $0=$ strongly disagree, $1=$ strongly agree. 


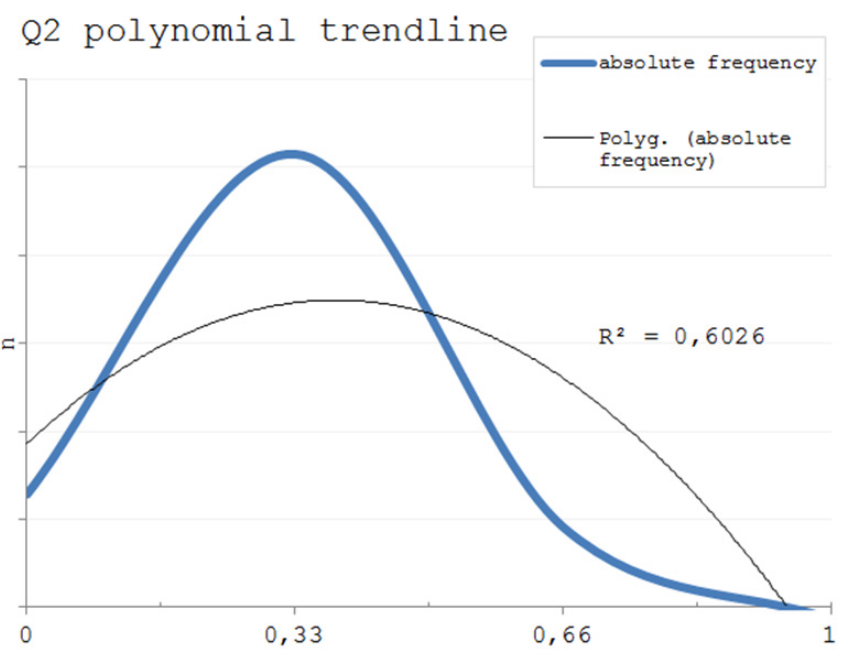

Fig. 2 - Q2 line chart with trend line. Source: authors

Here, the line chart represents opinion polarity using simple Gauss distribution model. The graph shows that a moderately disagreeing opinion largely prevails. The trend line also suggests greater expressiveness in the disagreeing field. Assuming that the more the $\mathrm{R}^{2}$ approximates to 1 , the more reliable the results, it means a mean reliability $\left(\mathrm{R}^{2}=0.6026\right)$ in this case.

Table 6 shows the results of testing the relationships in analysing the research question Q2a. The Pearson's Chi-squared test with the significance level of $\alpha=0.05$ was used.

Tab. 6 - Q2a Chi-squared Test and p-value. Source: authors

\begin{tabular}{|l|}
\hline Pearson's Chi-squared test with simulated $\mathrm{p}$-value (based on 5000 replicates) \\
\hline $\mathrm{H}_{0}:$ Variables are independent (no interaction between variables) \\
\hline $\mathrm{H}_{1}:$ Variables are dependent (interaction between variables) \\
\hline$\chi^{2}=23.546 ; \mathrm{DF}=\mathrm{n} / \mathrm{a} ; \mathrm{p}$-value $=0.463$ \\
\hline
\end{tabular}

The results in Table 6 show that a statistically significant relationship between how entrepreneurs perceive the appropriateness of the setting of state's financial support for entrepreneurship and the line of business was not proved. Therefore, it can be concluded that the research question Q2a has not been proved.

Table 7 shows the nominal values for the examined Claim Q2b in relation to the size of the companies surveyed. The table also lists the ordinal mean values and discrete ordinal variances. 
Tab. 7 - Pivot table for Q2b absolute frequency and Statistical characteristics. Source: authors

\begin{tabular}{|c|c|c|c|c|c|c|c|c|}
\hline \multirow{2}{*}{$\begin{array}{l}\text { Q2 / } \\
\text { number of } \\
\text { employees } \\
\text { (company } \\
\text { size) }\end{array}$} & \multicolumn{2}{|c|}{ Agree (n) } & \multirow{2}{*}{$\begin{array}{c}- \\
\text { No } \\
\text { idea }\end{array}$} & \multicolumn{2}{|c|}{ Disagree $(n)$} & \multirow[b]{2}{*}{$\begin{array}{l}\text { Total } \\
(n)\end{array}$} & \multicolumn{2}{|c|}{$\begin{array}{l}\text { Statistical } \\
\text { indicators }\end{array}$} \\
\hline & $\begin{array}{c}\text { Completely } \\
\text { agree }\end{array}$ & agree & & disagree & $\begin{array}{c}\text { Completely } \\
\text { disagree }\end{array}$ & & $\operatorname{med}(x)$ & dorvar \\
\hline$<10$ & 1 & 64 & 240 & 331 & 104 & 740 & 3.70 & 0.90 \\
\hline $10-50$ & 0 & 25 & 95 & 153 & 33 & 306 & 3.72 & 0.82 \\
\hline $50-250$ & 1 & 18 & 23 & 46 & 7 & 95 & 3.62 & 0.97 \\
\hline Total (n) & 2 & 107 & 358 & 530 & 144 & 1141 & & \\
\hline
\end{tabular}

The research question $\mathrm{Q} 2 \mathrm{~b}$ addresses whether the company size is a factor in perceiving the setup of a governmental financial support of entrepreneurship as appropriate. Medium-sized Enterprises (50 - 250 employees) expressed the highest degree of agreement $[(\operatorname{med}(\mathrm{x})=3.62)]$, their answers show the greatest heterogeneity (dorvar $=0.97)$. On the other hand, Small Enterprises $(10-50$ employees $)$ expressed the smallest degree of agreement $[(\operatorname{med}(\mathrm{x})=3.72)]$; the answers of the latter also showed the greatest homogeneity (dorvar $=0.82$ ).

Table 8 shows the results of testing the relationships in analysing the Research Question Q2b. The Pearson's Chi-squared test with the significance level of $\alpha=0.05$ was used.

Tab. 8 - Q2b Chi-squared Test and p-value. Source: authors

Pearson's Chi-squared test with simulated p-value (based on 5000 replicates)

$\mathrm{H}_{0}$ : Variables are independent (no interaction between variables)

$\mathrm{H}_{1}$ : Variables are dependent (interaction between variables)

$\chi^{2}=22.257 ; \mathrm{DF}=\mathrm{n} / \mathrm{a} ; \mathrm{p}$-value $=0.011$

The results in Table 8 show that a statistically significant relationship between how entrepreneurs perceive the appropriateness of the setup of governmental financial support of entrepreneurship and the company size ( $\mathrm{p}$-value $=0.011)$ was demonstrated. Therefore, it can be concluded that the research question $\mathbf{Q} 2 \mathbf{b}$ has been proved.

The third research question (Q3) focuses on analysing whether entrepreneurs perceive reduction in the administrative burden over the last five years. The question was further analysed in relation to the line of business and company size.

The research found out that only $11.13 \%$ of the entrepreneurs surveyed agree that the administrative burden has reduced in recent five years. As many as $78 \%$ of entrepreneurs do not agree with this claim. A neutral statement was indicated by $10.87 \%$ of the respondents. To sum up, most of the entrepreneurs are dissatisfied with the administrative burden in business. The research question Q3 - that more than $60 \%$ of SMEs disagree with the fact that the administrative burden has reduced over the last five years - has been proved. 
Table 9 shows the nominal values for the examined Claim Q3a in relation to the line of business of the companies surveyed. The table also lists the ordinal mean values and discrete ordinal variances.

Tab. 9 - Pivot table for Q3a absolute frequency and Statistical characteristics. Source: authors

\begin{tabular}{|l|c|c|c|c|c|c|c|c|}
\hline \multirow{2}{*}{$\begin{array}{l}\text { Q3 / } \\
\text { sector }\end{array}$} & \multicolumn{2}{|c|}{ Agree (n) } & - & \multicolumn{2}{c|}{ Disagree $(n)$} & \multicolumn{2}{c|}{$\begin{array}{c}\text { Statistical } \\
\text { Total } \\
\text { indicators }\end{array}$} \\
\cline { 2 - 10 } & $\begin{array}{c}\text { Completely } \\
\text { agree }\end{array}$ & agree & $\begin{array}{c}\text { No } \\
\text { idea }\end{array}$ & disagree & $\begin{array}{c}\text { Completely } \\
\text { disagree }\end{array}$ & $n$ & med( $(x)$ & dorvar \\
\hline Agriculture & 0 & 1 & 2 & 19 & 7 & 29 & 4.11 & 0.62 \\
\hline $\begin{array}{l}\text { Construction } \\
\text { industry }\end{array}$ & 3 & 16 & 12 & 69 & 32 & 132 & 4.00 & 1.02 \\
\hline $\begin{array}{l}\text { Manufactur- } \\
\text { ing }\end{array}$ & 4 & 14 & 20 & 91 & 53 & 182 & 4.08 & 0.94 \\
\hline Trade & 5 & 19 & 36 & 143 & 69 & 272 & 4.03 & 0.92 \\
\hline $\begin{array}{l}\text { Transporta- } \\
\text { tion }\end{array}$ & 0 & 7 & 6 & 28 & 8 & 49 & 3.91 & 0.91 \\
\hline $\begin{array}{l}\text { Other serv- } \\
\text { ices }\end{array}$ & 8 & 40 & 37 & 204 & 74 & 363 & 3.97 & 0.96 \\
\hline Combination & 0 & 10 & 11 & 59 & 34 & 114 & 4.11 & 0.88 \\
\hline Total $(n)$ & 20 & 107 & 124 & 613 & 277 & 1141 & & \\
\hline
\end{tabular}

The research question Q3a inquires whether the line of business is a factor in perceiving whether or not the administrative burden has reduced over the last five years. Transportation enterprises expressed the highest degree of agreement $[(\operatorname{med}(\mathrm{x})=3.91)]$ for this claim, their answers show a relatively high degree of homogeneity (dorvar $=0.91)$. On the contrary, the lowest levels of agreement $[\operatorname{med}(\mathrm{x})=4.11)]$ were expressed by entrepreneurs that do business in multiple areas at a time.

The polarity of views on Q3 is visualised in the Gauss chart below (blue) with a polynomial trend line (black thin) with the reliability value $\left(\mathrm{R}^{2}\right)$ where the following applies to the axis $\mathrm{x}$ scale: 0 $=$ totally disagree, $1=$ totally agree. 


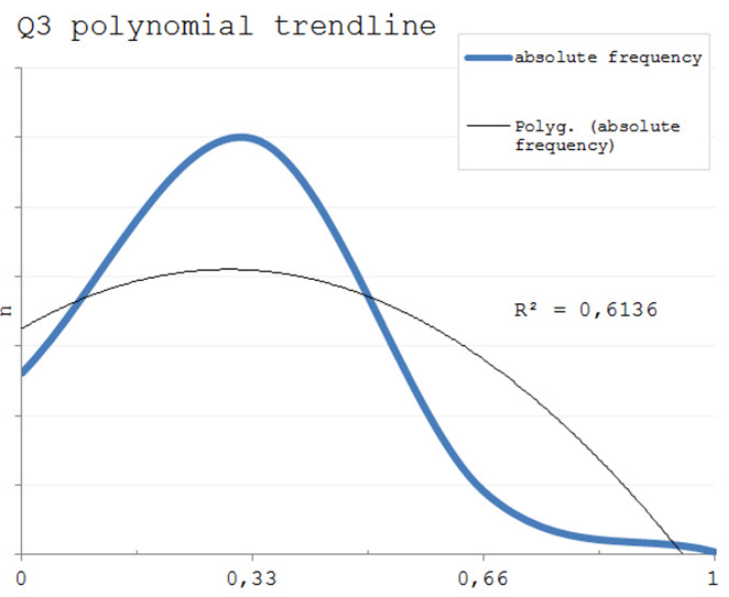

Fig. 3 -Q3 line chart with trendline. Source: authors

Here, the line chart represents opinion polarity using simple Gauss distribution model. The graph shows that a moderately disagreeing opinion largely prevails. The trend line also suggests greater expressiveness in the disagreeing field. Assuming that the more the R2 approximates to 1 , the more reliable the results, it means a mean reliability $\left(\mathrm{R}^{2}=0.6136\right)$ in this case.

Table 10 shows the results of testing the relationships in analysing the research question Q3a. The Pearson's Chi-squared test with the significance level of $\alpha=0.05$ was used.

Tab. 10 - Q3a Chi-squared Test and p-value. Source: authors

\begin{tabular}{|l|}
\hline Pearson's Chi-squared test with simulated $\mathrm{p}$-value (based on 5000 replicates) \\
\hline $\mathrm{H}_{0}:$ Variables are independent (no interaction between variables) \\
\hline $\mathrm{H}_{1}:$ Variables are dependent (interaction between variables) \\
\hline$\chi^{2}=22.334 ; \mathrm{DF}=\mathrm{n} / \mathrm{a} ; \mathrm{p}$-value $=0.558$ \\
\hline
\end{tabular}

The results in Table 10 show that a statistically significant relationship between perceiving reduction in the administrative burden over the most recent five years and the line of business was not discovered. Therefore, it can be concluded that the research question Q3a has not been proved.

Table 11 shows the nominal values for the examined Claim Q3b in relation to the size of the companies surveyed. The table also lists the ordinal mean values and discrete ordinal variances. 
Tab. 11 - Pivot table for Q3b absolute frequency and Statistical characteristics. Source: authors

\begin{tabular}{|c|c|c|c|c|c|c|c|c|}
\hline \multirow{2}{*}{$\begin{array}{l}\text { Q3 / } \\
\text { sector }\end{array}$} & \multicolumn{2}{|c|}{ Agree (n) } & \multirow{2}{*}{$\begin{array}{c}- \\
\text { No } \\
\text { idea }\end{array}$} & \multicolumn{2}{|c|}{ Disagree (n) } & \multirow{2}{*}{$\begin{array}{l}\text { Total } \\
\text { (n) }\end{array}$} & \multicolumn{2}{|c|}{$\begin{array}{l}\text { Statistical } \\
\text { indicators }\end{array}$} \\
\hline & $\begin{array}{c}\text { Completely } \\
\text { agree }\end{array}$ & agree & & disagree & $\begin{array}{c}\text { Completely } \\
\text { disagree }\end{array}$ & & $\operatorname{med}(x)$ & dorvar \\
\hline$<10$ & 11 & 72 & 91 & 389 & 177 & 740 & 4.00 & 0.95 \\
\hline $10-50$ & 6 & 27 & 23 & 169 & 81 & 306 & 4.07 & 0.92 \\
\hline $50-250$ & 3 & 8 & 10 & 55 & 19 & 95 & 3.98 & 0.93 \\
\hline Total (n) & 20 & 107 & 124 & 613 & 277 & 1141 & & \\
\hline
\end{tabular}

The research question Q3b addresses whether the company size is a factor for perceiving whether or not the administrative burden has reduced over the last five years. Medium-sized Enterprises (50-250 employees) expressed the highest degree of agreement $[(\operatorname{med}(\mathrm{x})=3.98)]$, their answers show a relatively high extent of homogeneity (dorvar $=0.93)$. Small Enterprises $(10-50$ employees) expressed the smallest degree of agreement $[(\operatorname{med}(\mathrm{x})=4.07)]$; the answers of the latter also showed the greatest homogeneity (dorvar $=0.92$ ).

Table 12 shows the results of testing the relationships in analysing the research question Q3b. The test made use of Pearson's Chi-squared test with the significance level of $\alpha=0.05$.

Tab. 12 - Q3b Chi-squared Test and p-value. Source: authors

\begin{tabular}{|l|}
\hline Pearson's Chi-squared test with simulated $\mathrm{p}$-value (based on 5000 replicates) \\
\hline $\mathrm{H}_{0}:$ Variables are independent (no interaction between variables) \\
\hline $\mathrm{H}_{1}:$ Variables are dependent (interaction between variables) \\
\hline$\chi^{2}=8.282 ; \mathrm{DF}=\mathrm{n} / \mathrm{a} ; \mathrm{p}$-value $=0.394$ \\
\hline
\end{tabular}

The results in Table 12 show that a statistically significant relationship between perception in reduction of the administrative burden for businesses over the last five years and the company size was not proved. Therefore, it can be concluded that the research question Q3b has not been proved.

\section{CONCLUSION AND DICUSSION}

There are many factors that influence competitiveness of enterprises within their business environment. Undoubtedly, one of the factors is the state, of which role and interventions in the business environment were analysed in this paper through opinions of small and medium-sized enterprises in the Czech Republic. In the context of the research, it was discovered that $60 \%$ of the entrepreneurs surveyed disagree with the claim that the state creates a favourable competitive environment for businesses. An agreement was expressed by mere $8 \%$ of respondents. This result demonstrates entrepreneurs' very critical view of the state's role within the business environment. The same finding was reached by Hamplová and Provazníková (2015) as they state that 
'in assessing the attitudes of Czech entrepreneurs, we came to the conclusion that their views of the support and the society-wide importance of small and medium-sized businesses are very critical. The reason for this criticism is neither connected with administrative barriers in business nor the work of authorities representing the state administration and business regulation.'

We analysed the state's role within the business environment from two perspectives: company sizes and lines of business. Based on the results of the analyses, it can be concluded that a relationship between the positive perception of the state's activity within the business environment and the line of business was proved. This may indicate a different level of legislative regulation of different sectors in the economy. In contrast, in terms of business size, no correlation between perception of the role of the state within the business environment and a company size was proved.

In terms of perception of the state's financial support of entrepreneurs, it was found out that almost $60 \%$ disagree with this claim. The disagreement means that entrepreneurs do not know or do not see any financial incentive for businesses from the state. In this area, the relationship of responses on company sizes was proved which may suggest the support of individual company sizes and influencing their competitiveness. Various company sizes can perceive a governmental financial support in different ways whether it is because some financial supports are limited by a company size or due to indifference towards governmental financial stimuli. Any dependence on the line of business was not proved, which means that the perception of "favouritism" of some industries was not proved either.

During the examination of the administrative burden and perception of its development it, was revealed that only $11.13 \%$ of entrepreneurs agree with the statement that the administrative burden has reduced over the last five years. As many as $78 \%$ of entrepreneurs do not agree with this claim. The relationship was not proved for neither the company size nor the line of business in this area.

This research has several limitations. Primarily, there is a territorial restriction since the survey was conducted only in the Czech Republic so its results cannot be considered generally applicable. The questions respondents were asked might have been incorrectly formulated or misunderstood by the respondents.

\section{Acknowledgements}

This paper was supported by the Project RO FaME/2016: Podnikatel'ské prostredie MSP: determinanty kvality a podnikatelské riziká.

\section{References}

1. Bartoš, P., Rahman, A., Horák, J., Jacová, H. (2015). Education and Entrepreneurship in The SME Segment In Economic Transformation. Economics and Sociology, 8(2), 227-239. DOI: 10.14254/2071-789X.2015/8-2/16.

2. Baláž, P., Hamara, A., Sopková, G. (2015). Konkurencieschopnost’ a jej vyżnam v narodnej ekonomike. Bratislava: Sprint.

3. Balcerzak, A. P. (2009). Effectiveness of the Institutional System Related to the Potential of the Knowledge Based Economy. Ekonomista, 6(1), 711-739. 
4. Belanová, K. (2014). Komparácia kvality podnikatel’ského prostredia v krajinách Vyšehradskej štvorky s osobitným akcentom na dostupnost’ finančných zdrojov. Biatec, Vol. 22, No.1, pp. 12-17.

5. Belás, J., Demjan, V., Habánik, J., Hudáková, M., Sipko, J. (2015). The business environment of Small and medium-sized companies in selected regions of the Czech Republic and Slovakia. E+M. Ekonomie a Management, 2015, 18 (1), 95-110.

6. Bhaird, C. M. (2010). Resourcing Small and Medium Sized Enterprises. Springer Verlag: Berlin, 2010.

7. Butoracová Šindleryová, I., Morovská, I. (2009) Entrepreneurship Environment in the Slovak Republic from the point of Regional Innovation Perspectives and Development. Retrieved 6.01.2017 from http://www.pulib.sk/elpub2/FM/Kotulic10/index.html.

8. Djankov, S., La Porta, R., Lopez-de-Silanes, F., Shleifer, A. (2002). The regulation of entry. The Quarterly Journal of Economics, 117 (1), 1-37. doi: 10.1162/003355302753399436.

9. Eric, D., Beraha, I., Djuricin, S., (2011), Financing innovative small and medium-sized enterprises in times of crisis. Revista Romana de Economie, Romanian Journal of Economics, Anul XXI, 33(2), 59-74.

10. Estrin, S., Korosteleva, J., Mickiewicz, T. (2013). Which institutions encourage entrepreneurial growth aspirations? Journal of Business Venturing, 28 (4), 564-580. doi:10.1016/j.jbusvent.2012.05.001.

11. Hamplova, E., Provaznikova, K. (2015). Opinion and Attitudes of Entrepreneurs of Small and Medium-Sized Business in the Czech Republic Conditions. Procedia Economics and Finance. 23, 942-947. doi: 10.1016/S2212-5671(15)00438-4.

12. Henderson, J., Weiler, S. (2010). Entrepreneurs and job growth: probing the boundaries of time and space. Economic Development Quarterly, 24 (1), 23 - 32. doi: 10.1177/08912424093509 17.

13. Kaplanova, P. (2016). Public goods as factors of a local economic development in Slovakia. Administratie si Management Public, (26), 6-24.

14. Ključnikov, A., Belás, J., Kozubíková, L., Paseková, P. (2016). Th e Entreprenurial Perception of SME Business Environment Quality in the Czech Republic. Journal of Competitiveness, 8 (1), 66-81.

15. Kordalska, A., Olczyk, M. (2016). Global Competitiveness and Economic Growth: A OneWay or Two-Way Relationship? Equilibrium. Quarterly Journal of Economics and Economic Policy, 11(1), 121-142.

16. Kubátová, K. et al. (2012). Podnikeatelské prostredé v EU z blediska verejných financí. Bratislava: Eurokódex.

17. La Porta, R., Lopez-de-Silanes, F., Shleifer, A., Vishny, R. (1999). The quality of government. Journal of Law, Economics and Organisation, 15 (1), 222-279.

18. Mathur, A. (2011). Beyond Bankruptcy: Does the Bankruptcy Code Provide a Fresh Start to Entrepreneurs? Working Paper. USA: Office of Advocacy.

19. Májková, M. (2012). Mojnosti financovania malych a strednych podnikov v SR. Brno: Tribun. 
20. Muhammad, M.Z., et al. (2010). Small and medium enterprises (SMEs) competing in the global business environment: a case of Maaysia. International Business Research, 3(1), pp. 66-75.

21. Pavelková, D., et al. (2009). Klastry a jejich vliv na výkonnost firem. Prague: Grada.

22. Salavou, H., Baltas, G., and Lioukas, S. (2004). Organizational innovation in SMEs: the importance of strategic orientation and competitive structure. European Journal of Marketing, 38 (9-10), pp. 1091-1112.

23. Shuying, Z., Mei, Z. (2014), Theory of SMEs financial risk prevention and control, International Conference on Education, Management and Computing Technology (ICEMCT 2014), 514-517.

24. Smékalová, L., Hájek, O., Belás, J., Macháček, J. (2014). Perception of Small and Medium Entrepreneurship in the Czech Republic. Journal of Competitiveness, 6 (4), pp. 41-49.

25. Whittaker, J., Burns, M., Beveren, J. V. (2003). Understanding and measuring the effect of social capital on knowledge transfer within clusters of small-medium enterprises. Paper presented at the 16th Annual Conference, University of Ballarat, Ballarat, Australia.

26. Zuzek, D. K. (2015), The Importance of Small and Medium-Sized Enterprises in the Development of the Region on the Example of the Malopolska Province. Proceedings of the 2015 International Conference "ECONOMIC SCIENCE FOR RUR AL DEVELOPMENT" NO39 Jelgava, LLU ESAF, 23-24 April 2015, 246-252. Retrieved 6.01.2016 from Available at: http://llufb.llu.lv/conference/economic_science_rural/2015/Latvia_ESRD_39_2015246-252.pdf

\section{Contact information}

Ing. Kamil Dobes, Ph.D.

Department of Economics

Faculty of Management and Economics

Tomas Bata University in Zlin

Mostni 5139, 76001 Zlin. Czech Republic

E-mail:dobes@fame.utb.cz.

Prof. Eng Sebastian Kot, Ph.D.

The Management Faculty,

Crestochowa University of Technology

Armii Krajowej 19B,

42-200, Czestochowa, Poland

Faculty of Economic Sciences and IT,

North-West University, South Africa

E-mail:sebacat@_zim.pcr.crest.pl

Mgr. Jan Kramolis, Ph.D.

Department of Economics

Faculty of Management and Economics

Tomas Bata University in Zlín

Mostni 5139, 76001 Zlin, Czech Republic

E-mail:kramolis@fame.utb.cz. 
JUDr. Ing. Gabriela Sopková, PhD.

Faculty of Commerce

University of Economics Bratislava

Dolnozemská cesta 1/b, 85235 Bratislava 5, Slovak Republic

E-mail:gabika.sopkova@gmail.com 